\title{
The efficiency of immobilised glutamate oxidase decreases with surface enzyme loading: an electrostatic effect, and reversal by a polycation significantly enhances biosensor sensitivity
}

\author{
Colm P. McMahon, ${ }^{a}$ Gaia Rocchitta, ${ }^{a b}$ Pier A. Serra, ${ }^{a b}$ Sarah M. Kirwan, ${ }^{a}$ John P. Lowry ${ }^{b}$ and \\ Robert D. O’Neill ${ }^{* a}$
}

Received 15th August 2005, Accepted 17th October 2005

First published as an Advance Article on the web 9th November 2005

DOI: 10.1039/b511643k

The apparent Michaelis constant, $K_{\mathrm{M}}$, for glutamate oxidase (GluOx) immobilised on $\mathrm{Pt}$ electrodes increased systematically with enzyme loading. The effect was due, at least in part, to electrostatic repulsion between neighbouring oxidase molecules and the anionic substrate, glutamate (Glu). This understanding has allowed us to increase the Glu sensitivity of GluOxbased amperometric biosensors in the linear response region $\left(100 \pm 11 \mathrm{nA} \mathrm{cm}^{-2} \mu \mathrm{M}^{-1}\right.$ at $\mathrm{pH} 7.4$; $\mathrm{SD}, n=23$ ) by incorporating a polycation (polyethyleneimine, PEI) to counterbalance the polyanionic protein. Differences in the behaviour of glucose biosensors of a similar configuration highlight a limitation of using glucose oxidase as a model enzyme in biosensor design.

\section{Introduction}

The development of devices for monitoring L-glutamate (Glu) has become a significant research area due to the important role this amino acid plays in a range of complex matrices, including food processing, ${ }^{1}$ cell cultures, ${ }^{2}$ tissue slices ex vivo, ${ }^{3}$ and intact brain in vivo. ${ }^{4-7}$ As an excitatory amino acid, Glu is the most widespread neurotransmitter in the mammalian CNS and has been implicated in a number of neurological disorders. ${ }^{8}$ Systems for monitoring Glu in brain extracellular fluid (ECF) have therefore become an important goal in the analytical and neurobiological sciences in recent years.

The high spatial and temporal resolution achievable with implantable amperometric biosensors has motivated the design of a number of Glu biosensor configurations incorporating the enzyme glutamate oxidase (GluOx). ${ }^{6,7,9-15}$ Based on Pt wire modified with GluOx immobilised using PPD, poly(o-phenylenediamine), the $\mathrm{Pt} / \mathrm{GluOx} / \mathrm{PPD}$ cylinder biosensor, designed specifically for detection of Glu in vivo, ${ }^{15}$ has shown promising responses for monitoring Glu in the alert brain implanted with probes of moderate sensitivity in the linear response region $\left(\sim 20 \mathrm{nA} \mathrm{cm}{ }^{-2} \mu \mathrm{M}^{-1}\right),{ }^{16}$ whereas sensors of lower sensitivity $\left(\sim 10 \mathrm{nA} \mathrm{cm}^{-2} \mu \mathrm{M}^{-1}\right)$ failed to detect Glu changes associated with mild behavioural stimulation. ${ }^{17}$ Thus, there is an urgent need to increase Glu biosensor sensitivity for a range of applications, including detection of small changes in ECF Glu levels. A recent study of the same Pt/GluOx/PPD design, but based on smaller Pt disks, provided a useful increase in Glu sensitivity $\left(\sim 30 \mathrm{nA} \mathrm{cm}{ }^{-2} \mu \mathrm{M}^{-1}\right)$, and showed that both geometrical configurations had good oxygen tolerance. ${ }^{18}$ Here we investigate the effects of surface enzyme loading on the Glu

${ }^{a}$ UCD School of Chemistry and Chemical Biology, University College Dublin, Belfield, Dublin 4, Ireland.E-mail: Robert.ONeill@UCD.ie;

Fax: +353-1-7162127; Tel: +353-1-7162314

${ }^{b} U C D$ School of Biomolecular and Biomedical Sciences, University

College Dublin, Belfield, Dublin 4, Ireland response of both cylinder and disk Pt/GluOx/PPD designs, a study which has led to a significant increase in linear region sensitivity $\left(\sim 100 \mathrm{nA} \mathrm{cm} \mathrm{cm}^{-2} \mu \mathrm{M}^{-1}\right)$ of these implantable devices.

FAD is the prosthetic group of many oxidases, including GluOx, ${ }^{19}$ and molecular oxygen the co-substrate, which reoxidises the $\mathrm{FADH}_{2}$ to form $\mathrm{H}_{2} \mathrm{O}_{2}$ (reactions (1) and (2)) that can be detected amperometrically (reaction (3)). A number of sophisticated mathematical models of the behaviour of enzymes in membranes have been described. ${ }^{20-24}$ These complex analyses are often needed to understand and optimise the behaviour of thick and/or conducting layers. ${ }^{24,25}$ However, a recent study has shown that substrate diffusion is not limiting for PPD layers incorporating enzyme, due to their relatively small thickness. ${ }^{26}$ Therefore, the basic MichaelisMenten enzyme parameters used here provide more readily accessible insights into factors affecting the responsiveness of biosensors fabricated from ultrathin $(10-30 \mathrm{~nm})^{27-30}$ insulating polymers, such as PPD.

$$
\begin{aligned}
& \text { L-glutamate }+\mathrm{H}_{2} \mathrm{O}+\text { GluOx/FAD } \rightarrow \alpha \text {-ketoglutarate }+ \\
& \mathrm{NH}_{3}+\mathrm{GluOx} / \mathrm{FADH}_{2} \\
& \mathrm{GluOx} / \mathrm{FADH}_{2}+\mathrm{O}_{2} \rightarrow \mathrm{GluOx} / \mathrm{FAD}+\mathrm{H}_{2} \mathrm{O}_{2} \\
& \mathrm{H}_{2} \mathrm{O}_{2} \rightarrow \mathrm{O}_{2}+2 \mathrm{H}^{+}+2 \mathrm{e}
\end{aligned}
$$

A two-substrate model is necessary to describe the kinetics of oxidase enzymes under conditions of varying concentration of both substrate and $\mathrm{O}_{2} \cdot{ }^{31,32}$ When the concentration of the co-substrate is constant, however, the two-substrate equation simplifies to the one-substrate Michaelis-Menten form (eqn (4)), where the current density for the biosensor Glu response, $J_{\mathrm{Glu}}$, is a measure of the overall rate of the enzyme reaction, and $J_{\max }$ is the $J_{\mathrm{Glu}}$ value at enzyme saturation. Different values of $J_{\max }$, determined under the same conditions, reflect differences in the amount of active enzyme on the 
surface, provided the sensitivity of the electrode to $\mathrm{H}_{2} \mathrm{O}_{2}$ (reaction (3)) does not vary, as was the case for the PPDmodified Pt cylinders and disks used here. ${ }^{33-35}$

$$
J_{\mathrm{Glu}}=\frac{J_{\max }}{1+\frac{K_{\mathrm{M}}}{[\mathrm{Glu}]}}
$$

The Michaelis constant, $K_{\mathrm{M}}$, is defined in terms of the rate constants for the generalised reactions (reaction (5)) describing the conversion of substrate $(\mathrm{S})$ to product $(\mathrm{P})$, catalysed by enzyme (E); see eqn (6). When eqn (4) is used to approximate the two-substrate case, the $K_{\mathrm{M}}$ is more complex, containing cosubstrate terms. $K_{\mathrm{M}}$ is then the apparent Michaelis constant and phenomenologically defines the concentration of substrate that gives half the $J_{\max }$ response. Thus, changes in $K_{\mathrm{M}}$ are sensitive to the binding constant, $k_{1}$, and have often been interpreted in terms of barriers to substrate/enzyme binding, ${ }^{36,37}$ as well as changes in oxygen demand. ${ }^{38}$ Here we present data that suggest that GluOx molecules $(\mathrm{pI}=6.2)^{19}$ packed on an electrode surface represent an electrostatic barrier to Glu accessing the enzyme active site; this limits enzyme loading as a stand-alone strategy for increasing sensitivity of Glu biosensors in their linear response region, a design feature which is crucial for successful applications in neurochemical studies where Glu concentrations are in the low micromolar range. ${ }^{39,40}$

$$
\begin{gathered}
\mathrm{E}+\mathrm{S} \underset{k_{-1}}{\stackrel{k_{1}}{\rightleftarrows}} \mathrm{ES} \stackrel{k_{2}}{\longrightarrow} \mathrm{E}+\mathrm{P} \\
K_{\mathrm{M}}=\frac{k_{-1}+k_{2}}{k_{1}}
\end{gathered}
$$

\section{Experimental}

Biosensors were fabricated from Teflon $^{\mathbb{R}}$-coated Pt wire (diameter $125 \mu \mathrm{m}$ ), either in the form of disks or cylinders $1 \mathrm{~mm}$ long. Glucose oxidase (GOx, EC 1.1.3.4, Sigma, $200 \mathrm{U} \mathrm{mL}^{-1}$ ) or GluOx (EC 1.4.3.11, Yamasa Corp., Japan, $200 \mathrm{U} \mathrm{mL}^{-1}$ ) was deposited onto the metal surface by dipevaporation (1-4 dips), and then immobilised by amperometric electropolymerisation $(+700 \mathrm{mV}$ vs. SCE) in phosphatebuffered saline (PBS, pH 7.4) containing $300 \mathrm{mM}$ o-phenylenediamine, as described previously, to form $\mathrm{Pt} / \mathrm{GOx} / \mathrm{PPD}$ and Pt/GluOx/PPD biosensors, respectively. ${ }^{15}$ Additional sets of biosensors were prepared by pre-coating the Pt surface with either the zwitterionic lipid phosphatidylethanolamine (PEA, type II-S, Sigma, $5 \mathrm{mg} \mathrm{mL}^{-1}$ in chloroform) or the polycation polyethyleneimine (PEI, Aldrich, $\mathrm{MW}_{\mathrm{r}} \sim 750 \mathrm{kDa}, 1 \%$ aqueous solution), also by dip evaporation, before enzyme deposition.

Experiments were computer controlled with data collection accomplished using either a Biodata Microlink interface or a National Instruments (NI, Austin, Texas) AT-MIO-16 data acquisition board linked to a low noise, low damping potentiostat (Biostat II, Electrochemical and Medical Systems, Newbury, UK). All electropolymerisations and calibrations were carried out amperometrically in quiescent PBS solution, $\mathrm{pH}$ 7.4: $\mathrm{NaCl}$ (BDH, AnalaR grade, $150 \mathrm{mM}$ ),
$\mathrm{NaH}_{2} \mathrm{PO}_{4}(\mathrm{BDH}$, AnalaR grade, $40 \mathrm{mM}$ ) and $\mathrm{NaOH}$ (Sigma, $40 \mathrm{mM}$ ). After rinsing and a settling period at $+700 \mathrm{mV} v$. SCE in $20 \mathrm{~mL}$ of fresh air-saturated PBS, calibrations were performed to determine the response of the biosensors to enzyme substate and $\mathrm{H}_{2} \mathrm{O}_{2}$.

Non-linear regression analysis (Prism 4.02, GraphPad Software Inc.) was carried out on the current density responses for each biosensor to determine the apparent MichaelisMenten constants, using eqn (4); see Fig. 1. The apparent Michaelis constant is symbolised by $K_{\mathrm{M}}(\mathrm{Glu})$ for GluOx and $K_{\mathrm{M}}(\mathrm{G})$ for GOx when required for clarity, but $K_{\mathrm{M}}$ otherwise.

Values reported are mean \pm SEM, unless stated otherwise, with $n$ being the number of biosensors. The significance of differences in the values of parameters determined for distinct populations of electrodes was calculated using Student's twotailed unpaired t-tests, with $p<0.05$ taken to indicate statistical significance.

\section{Results and discussion}

\section{Immobilisation of enzyme onto bare metal}

The response of a thin $(10-30 \mathrm{~nm})^{27-30}$ PPD-entrapped GluOx layer to substrate depends on two main factors: ${ }^{26}$ enzyme kinetics (reactions (1) and (2), and eqn (4)) and sensitivity of the composite device to $\mathrm{H}_{2} \mathrm{O}_{2}$ (reaction (3)). To determine the extent to which variations in $\mathrm{H}_{2} \mathrm{O}_{2}$ sensitivity would affect $J_{\text {max }}$ comparisons for different sensor types, two analyses were performed on $\mathrm{H}_{2} \mathrm{O}_{2}$ calibration data. There was no significant difference between the $\mathrm{H}_{2} \mathrm{O}_{2}$ slopes for bare disks $(n=51)$ and bare cylinders $(n=23): 2 \pm 8 \%$. This demonstrates that the efficiency of mass transport from the bulk solution is similar for the two forms of radial diffusion to electrodes of these dimensions over the time scale of the amperometric recording. Secondly, there was no correlation between $J_{\max }$ values and $\mathrm{H}_{2} \mathrm{O}_{2}$ slopes for biosensors $\left(R^{2}=0.036, n=23\right)$. These results are in line with literature reports that the $\mathrm{H}_{2} \mathrm{O}_{2}$ sensitivity of $\mathrm{Pt}$

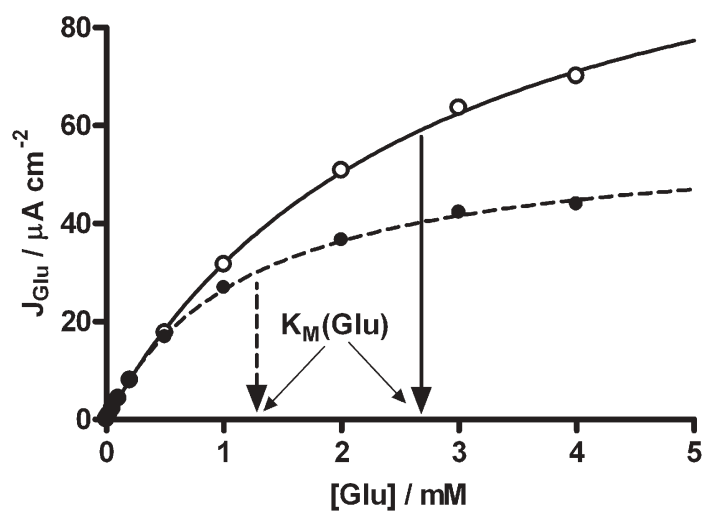

Fig. 1 Current densities from glutamate calibrations carried out in PBS (pH 7.4) at $+700 \mathrm{mV}$ vs. SCE with two Pt/GluOx/PPD disk biosensors showing different active enzyme loading, $J_{\max }$. The following non-linear regression parameters were obtained for the high (-) and the low (---) responses: $J_{\max } / \mu \mathrm{A} \mathrm{cm} \mathrm{cm}^{-2}=120$ (high) and 60 (low); $K_{\mathrm{M}} / \mathrm{mM}=2.8$ (high) and 1.2 (low); $R^{2}>0.999$ in both cases (eqn (4)); see Fig. 2 for results from 67 Glu biosensors. The mean linear region Glu calibration slope for disk biosensors of this design was $30 \pm$ $2 \mathrm{nA} \mathrm{cm}^{-2} \mu \mathrm{M}^{-1}(n=46)$. 
is not affected by PPD and PPD-protein composites made under the conditions described here. ${ }^{29,33,34}$ Differences in $J_{\max }$ across sensor designs should therefore be a good reflection of differences in the amount of active enzyme present.

Because dip-evaporation is expected to lead to different amounts of deposited enzyme for each electrode, whose activity could be affected differently by the subsequent polymerisation step, it is not surprising that biosensors fabricated in this way from $125 \mu \mathrm{m}$ diameter cylinders or disks displayed a range of $J_{\max }$ values (see Fig. 1 and 2). Unexpectedly, however, there was also a strong dependence of $K_{\mathrm{M}}$ on GluOx loading $\left(J_{\max }\right)$ for disk-based Pt/GluOx/PPD biosensors (Fig. 1). Ideally (eqn (6)), $K_{\mathrm{M}}$ values should be independent of enzyme loading, but in practice several factors related to the density of GluOx on the surface could affect the apparent Michaelis constant, including steric and electrostatic hindrance of Glu (reaction (1)) by neighbouring enzyme molecules, and limited oxygen supply (reaction (2)). Thus, for example, a slight increase in $K_{\mathrm{M}}$ with enzyme loading for GOx-based glucose biosensors has been reported and discussed in terms of oxygen turnover. ${ }^{41}$ However, recent studies have shown that the Pt/GluOx/PPD disk-based Glu biosensors, which show higher Glu sensitivity than the corresponding cylinder-based devices (see Fig. 1), had a lower dependence on solution $\mathrm{pO}_{2}{ }^{18}$ indicating that increased oxygen demand cannot be used to explain the increase in $K_{\mathrm{M}}$ observed here.

To examine further the effects of GluOx loading on $K_{\mathrm{M}}(\mathrm{Glu})$, a regression analysis was performed on the respective $K_{\mathrm{M}}(\mathrm{Glu})$ and $J_{\max }$ values for Pt/GluOx biosensors fabricated from both disks and cylinders (Fig. 2). There was a significant correlation between these two paramaters (slope =

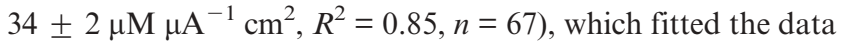
for both geometrical designs (see Fig. 2). It is clear, however, that the GluOx loading density was considerably greater on the disks than on the cylinders. This is consistent with retention of a dome of enzyme solution around the disk tip as it is removed vertically from the liquid during fabrication, as expected from surface tension considerations. Upon evaporation, the density of GluOx on the disk surface should therefore be higher than that achieved with the corresponding cylinder geometry. The magnitude of the increase in $K_{\mathrm{M}}(\mathrm{Glu})$ from

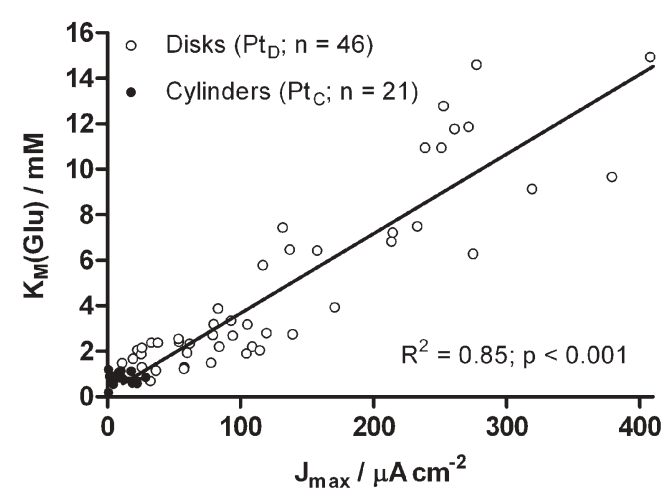

Fig. 2 Linear correlation analysis for $K_{\mathrm{M}}$ vs. $J_{\max }$ values obtained using eqn (4) (see Fig. 1) for Pt/GluOx/PPD biosensors based on cylinder $(n=21)$ and disk $(n=46)$ designs (slope $=34 \pm$ $\left.2 \mu \mathrm{M} \mu \mathrm{A}^{-1} \mathrm{~cm}^{2}, n=67\right)$. cylinders $(\sim 0.5 \mathrm{mM})$ to disks $(\sim 10 \mathrm{mM}$; see Fig. 2$)$ was approximately 20 -fold; this compares with only a 3-fold increase in $K_{\mathrm{M}}(\mathrm{G})$ for Pt/GOx over a similar range of $J_{\max }$ values, and therefore of oxygen demand. ${ }^{35}$ One explanation for these results is that the additional electrostatic repulsion between anionic Glu and the surface GluOx $(\mathrm{pI}=6.2)^{19}$ may reduce access by Glu to the enzyme (decreasing $k_{1}$, eqn (6)) as the GluOx loading builds up, an interaction not relevant to neutral glucose.

To determine whether the polymer contributed to the effects shown in Fig. 1 and 2, PPD-free Pt/GluOx biosensors $(n=4)$ were fabricated using glutaraldehyde as the immobilisation agent. Glu calibrations, performed after each of two enzyme layers was deposited in this way, showed that the second layer of GluOx resulted in an $80 \pm 20 \%$ increase in $J_{\max }$ and a $30 \pm$ $10 \%$ increase in $K_{\mathrm{M}}$ compared with layer $1(p<0.02)$, a trend similar to that for PPD-based electrodes. Furthermore, deposition of PPD after these calibrations led to only a small and statistically insignificant change in the $K_{\mathrm{M}}: 1.4 \pm 0.1$ to $1.7 \pm 0.1 \mathrm{mM}(p>0.13)$, indicating that neither the PPD polymer itself, nor diffusion through it, plays a major role in the effect of enzyme loading on $K_{\mathrm{M}}$.

Therefore, some increase in Glu sensitivity in the linear region $(\mathrm{LR})$ of the calibration response $\left(\mathrm{LR}\right.$ slope $\left.=J_{\max } / K_{\mathrm{M}}\right)$ is achievable by increasing the loading of GluOx in Pt/GluOx/ PPD biosensors ${ }^{18}$ (e.g., the higher LR slopes for disk biosensors in Fig. 1 compared with previous reports for PPD-based cylinder designs $\left.{ }^{12,15,16}\right)$. However, much of the additional enzyme activity $\left(J_{\max }\right)$ does not translate down to boosting the response at lower Glu concentrations due to an increased $K_{\mathrm{M}}$ value, possibly caused by an anionic electrostatic barrier associated with enzyme crowding. The following experiments were designed to test this hypothesis.

\section{Immobilisation of enzyme onto coated metal}

The polycation PEI, polyethyleneimine, has been used in a number of studies to stabilise enzymes, such as $\mathrm{GluOx}^{42}$ and lactate oxidase, ${ }^{43,44}$ and to neutralise the negative charge on carbon electrodes. ${ }^{45}$ PEI was therefore an ideal candidate in attempts here to reverse the proposed anionic electrostatic barrier associated with high GluOx loading. PEI (branched form, $\mathrm{MW}_{\mathrm{r}} \sim 750 \mathrm{kDa}, 1$ or $5 \%$ aqueous solution) was deposited onto bare $\mathrm{Pt}$ wire disks by dip evaporation, followed by GluOx immobilisation and electropolymerisation to form Pt/PEI/GluOx/PPD disk biosensors, as described for the Pt/GluOx/PPD electrodes. Calibrations with Glu showed that pre-coating the Pt with PEI led to a large decrease in the $K_{\mathrm{M}}: 0.65 \pm 0.05 \mathrm{mM}(\mathrm{PEI}, n=20)$ compared to $5.4 \pm 0.7 \mathrm{mM}$ (no PEI, $n=45, p<0.0001$ ), a finding consistent with a reduction in the repulsion between anionic Glu and the PEIcontaining enzyme layer (see Fig. 3).

An analysis for PEI-containing biosensors, similar to that in Fig. 2, showed that PEI reduced the regression slope by a factor of ten, but had no effect on the intercept which represents $K_{\mathrm{M}}(\mathrm{Glu})$ in the limit of zero loading of GluOx ( $\sim 0.4 \mathrm{mM}$, comparing favourably with the solution value of $0.2 \mathrm{mM}^{19}$ ). Thus, PEI did not significantly affect the interaction of Glu with GluOx when the enzyme molecules were widely separated (zero loading limit). This finding 


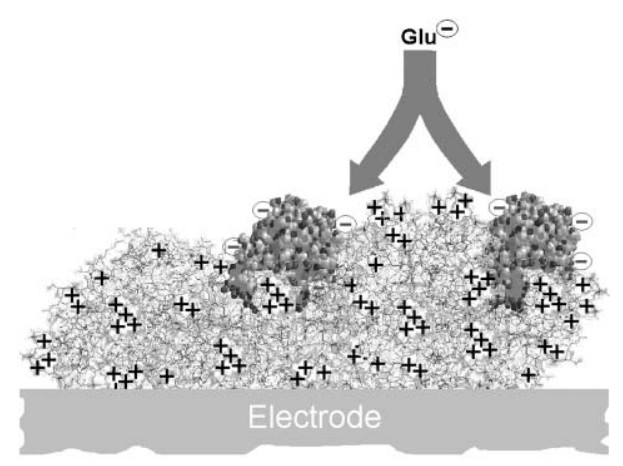

Fig. 3 Schematic representation of the immobilisation of glutamate oxidase molecules (GluOx, $140 \mathrm{kDa},{ }^{19}$ polyanionic) over a molecule of polyethyleneimine (PEI, $750 \mathrm{kDa}$, polycationic). The PEI helps reduce the electrostatic barrier between neighbouring enzymes and the anionic substrate (Glu), significantly decreasing the apparent Michaelis constant $\left(K_{\mathrm{M}}\right)$ for Glu and increasing Glu sensitivity in the analytically important linear response region.

provides evidence that the effect of PEI is not mediated by diffusion effects through the PEI/GluOx/PPD matrix, and is consistent with our 'ultrathin-layer' enzyme kinetic analysis, ${ }^{26}$ which avoids the concept of the Thiele modulus. ${ }^{32}$ It appears, therefore, that PEI specifically inhibits the repulsion between Glu and neighbouring GluOx molecules in the high loading, crowded, region (illustrated in Fig. 3), but does not modify significantly the interaction between Glu and its host enzyme molecule.

Two sets of control experiments were carried out to test the conclusion that electrostatics played a major role in the PEIreversal of the increase in $K_{\mathrm{M}}(\mathrm{Glu})$ caused by GluOx loading. In the first, to demonstrate that the effect was not simply due to the immobilisation of the enzyme on an organic layer as opposed to the bare metal, disk-based biosensors were prepared using a zwitterionic lipid, PEA, layer in place of the polycationic PEI. The globally neutral lipid coating had no significant effect on $K_{\mathrm{M}}(\mathrm{Glu}): 3.6 \pm 0.7 \mathrm{mM}, n=11 ; p>0.22$ compared with PEA absent. In the second, a PEI polycationic layer was included in GOx-based biosensors. The presence of PEI in the glucose biosensors had no significant effect on the $K_{\mathrm{M}}(\mathrm{G})$ value: $12.3 \pm 0.3 \mathrm{mM}(\mathrm{PEI}, n=4) ; 11.1 \pm 0.7 \mathrm{mM}$ (no PEI, $n=4$ ); $p>0.22$. These results, taken together, support the electrostatic hypothesis.

The combination of high $J_{\max }$ and low $K_{\mathrm{M}}$ for Pt/PEI/ GluOx/PPD disk biosensors gave rise to superb sensitivity to Glu (LR slope), the exact value depending on the amount of surface PEI. When a 5\% PEI solution was used in the dipevaporation procedure, subsequent Glu calibrations gave a LR slope of $62 \pm 5 \mathrm{nA} \mathrm{cm}^{-2} \mu \mathrm{M}^{-1}(n=12)$, compared with $100 \pm$ $5 \mathrm{nA} \mathrm{cm}^{-2} \mu \mathrm{M}^{-1}(n=8)$ for $1 \%$ PEI $(p<0.001)$. This latter value represents a new benchmark value (Fig. 4) which has not been surpassed by other Glu biosensor designs. $711,13,14,42,46,47$

One of the reasons for exploring the disk geometry in the design of implantable biosensors was the increased LR slope achieved through the extra loading available on disks. ${ }^{18}$ The final step in these studies was to investigate the effects of PEI on the LR sensitivity of cylinder-based Glu biosensors. As observed for the disk design, there was a substantial increase in

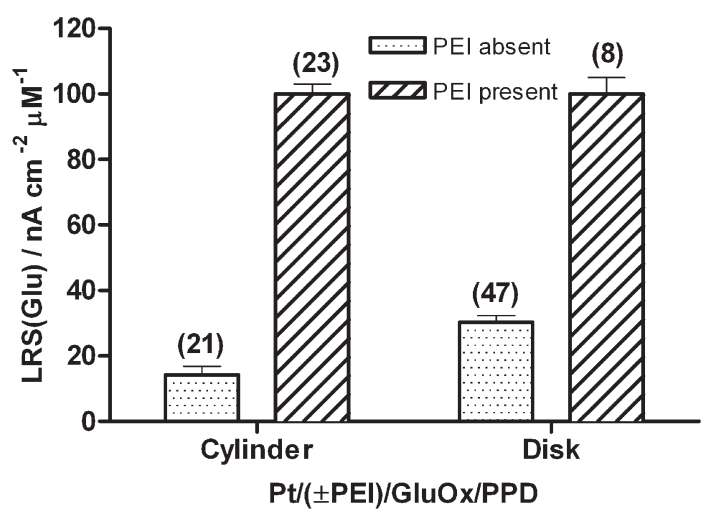

Fig. 4 The linear region calibration slope (LRS) for glutamate determined using cylinder and disk biosensors fabricated by immobilising GluOx on either bare Pt or PEI-coated Pt. Data are pooled for one dip of $1-5 \%$ PEI followed by $1-4$ dips of GluOx solution, except for PEI-modified disks (optimum 1\% PEI, 1-2 dips GluOx; see text). Mean \pm SEM with number of biosensors in brackets.

the LR slope for biosensors fabricated from PEI-coated Pt cylinders. Surprisingly, however, there was no significant difference between the responses for cylinder biosensors produced with different amounts of PEI and GluOx. All combinations of one dip of either a $1 \%$ or $5 \%$ PEI solution followed by either two or four dips of the enzyme solution gave similar responses $\left(\mathrm{nA} \mathrm{cm}^{-2} \mu \mathrm{M}^{-1}: 108 \pm 1, n=4 ; 100 \pm 4, n=\right.$ 11; $97 \pm 4, n=4$; and $96 \pm 3, n=4)$. These values were therefore pooled: $100 \pm 3 \mathrm{nA} \mathrm{cm}{ }^{-2} \mu \mathrm{M}^{-1}, n=23$. In an attempt to increase the sensitivity further, a layer-by-layer approach described in the literature for the fabrication of sensors using a variety of polyelectrolytes ${ }^{48-51}$ was investigated. This was found not to be advantageous here because the deposition of polycationic PEI over the polyanionic enzyme led to a marked loss of Glu sensitivity, presumably due to the large size of PEI molecules relative to GluOx (see Fig. 3).

The LR slopes for both cylinders and disks are compared in Fig. 4. The enhanced LR slope achieved through the extra loading on PEI-free disks ${ }^{18}$ was not apparent in the presence of PEI. Thus, the polycation also enhanced the deposition of the enzyme on the vertical cylinder surface during the dipevaporation process, and led to indistinguishably high sensitivities for the two PEI-coated geometries. The lack of a major effect of PEI on Glu sensitivity for redox hydrogel based biosensors reported previously ${ }^{42}$ may be due to the more dispersed distribution of enzyme in the hydrogel matrix. That regime coincides more with the limit of zero loading described here, where there was no effect of PEI on the $K_{\mathrm{M}}(\mathrm{Glu})$ value.

\section{Conclusions}

Taken together, the results indicate that the $K_{\mathrm{M}}$ for surfaceimmobilised GluOx increases systematically with enzyme loading, due in part to electrostatic repulsion between the anionic substrate and neighbouring enzyme molecules at neutral $\mathrm{pH}$. This effect was counteracted by pre-coating the metal surface with a polycationic (PEI), but not a zwitterionic (PEA), layer prior to enzyme deposition. The resulting Pt/PEI/GluOx/PPD biosensors of both cylinder and 
disk configurations displayed superb sensitivity in the linear Glu calibration region: $100 \pm 11 \mathrm{nA} \mathrm{cm}^{-2} \mu \mathrm{M}^{-1}(\mathrm{SD}, n=23)$ for cylinders; and $100 \pm 13 \mathrm{nA} \mathrm{cm}^{-2} \mu \mathrm{M}^{-1}(\mathrm{SD}, n=8)$ for disks.

Given the small area of these Pt disk sensors (similar to $0.5 \mathrm{~mm}$ cylinders made from $10 \mu \mathrm{m}$ diameter carbon fibre), ${ }^{7,47}$ biosensors based on this configuration would provide excellent Glu sensitivity and spatial resolution in neurochemical monitoring involving small brain areas or layered structures in vivo. ${ }^{11,52}$ The enhanced sensitivity of the cylinder design will allow these larger devices to find applications in larger brain regions, such as dorsal striatum and accumbens, where the greater signal strength will be an important advantage in early in vivo investigations. The results presented here also demonstrate some limitations of using GOx as a model enzyme for developing biosensors for other enzyme systems, and provide an explanation of why multiple dip-evaporation steps increased the LR slope for biosensors incorporating GOx, but not GluOx, in a previous study. ${ }^{15}$

\section{Acknowledgements}

This work was funded in part by Science Foundation Ireland (03/IN3/B376 and 04/BR/C0198). We thank Enterprise Ireland for a postgraduate research award (CMcM), Dr Kusakabe of Yamasa Corp., Japan, for a generous gift of glutamate oxidase, and UCD for financial support.

\section{References}

1 P. N. Nakorn, M. Suphantharika, S. Udomsopagit and W. Surareungchai, World J. Microbiol. Biotechnol., 2003, 19, 479-485.

2 R. Kurita, K. Hayashi, K. Torimitsu and O. Niwa, Anal. Sci., 2003, 19, 1581-1585.

3 M. Qhobosheane, D. H. Wu, G. R. Gu and W. H. Tan, J. Neurosci. Methods, 2004, 135, 71-78.

4 J. J. Burmeister and G. A. Gerhardt, Trends Anal. Chem., 2003, 22, 498-502.

5 Y. Matsushita, K. Shima, H. Nawashiro and K. Wada, J. Neurotrauma, 2000, 17, 143-153.

6 Y. Hu, K. M. Mitchell, F. N. Albahadily, E. K. Michaelis and G. S. Wilson, Brain Res., 1994, 659, 117-125.

7 N. V. Kulagina, L. Shankar and A. C. Michael, Anal. Chem., 1999, 71, 5093-5100.

8 B. Belsham, Hum. Pharmacol. Clin. Exp., 2001, 16, 139-146.

9 K. S. Chang, W. L. Hsu, H. Y. Chen, C. K. Chang and C. Y. Chen, Anal. Chim. Acta, 2003, 481, 199-208.

10 K. Nakajima, T. Yamagiwa, A. Hirano and M. Sugawara, Anal. Sci., 2003, 19, 55-60.

11 J. J. Burmeister and G. A. Gerhardt, Anal. Chem., 2001, 73, $1037-1042$.

12 J. M. Cooper, P. L. Foreman, A. Glidle, T. W. Ling and D. J. Pritchard, J. Electroanal. Chem., 1995, 388, 143-149.

13 S. Cosnier, C. Innocent, L. Allien, S. Poitry and M. Tsacopoulos, Anal. Chem., 1997, 69, 968-971.

14 R. D. O'Neill, S. C. Chang, J. P. Lowry and C. J. McNeil, Biosens. Bioelectron., 2004, 19, 1521-1528.

15 M. R. Ryan, J. P. Lowry and R. D. O’Neill, Analyst, 1997, 122, 1419-1424.

16 J. P. Lowry, M. R. Ryan and R. D. O’Neill, Anal. Commun., 1998, 35, 87-89.
17 J. P. Lowry, M. R. Ryan and R. D. O'Neill, in Monitoring Molecules in Neuroscience, ed. W. T. O'Connor, J. P. Lowry, J. J. O'Connor and R. D. O'Neill, National University of Ireland, Dublin, 2001, pp. 70-71.

18 C. P. McMahon and R. D. O’Neill, Anal. Chem., 2005, 77, 1196-1199.

19 H. Kusakabe, Y. Midorikawa, T. Fujishima, A. Kuninaka and H. Yoshino, Agric. Biol. Chem., 1983, 47, 1323-1328.

20 W. J. Albery and P. N. Bartlett, J. Electroanal. Chem., 1985, 194, 211-222.

21 P. N. Bartlett and K. F. E. Pratt, Biosens. Bioelectron., 1993, 8, 451-462.

22 C. Phanthong and M. Somasundrum, J. Electroanal. Chem., 2003, 558, $1-8$.

23 R. Baronas, F. Ivanauskas, F. Ivanauskas and J. Kulys, J. Math. Chem., 2004, 35, 199-213.

24 J. J. Gooding, E. A. H. Hall and D. B. Hibbert, Electroanalysis, 1998, 10, 1130-1136.

25 R. Baronas, F. Ivanauskas and J. Kulys, Sensors, 2003, 3, 248-262.

26 J. I. R. De Corcuera, R. P. Cavalieri and J. R. Powers, J. Electroanal. Chem., 2005, 575, 229-241.

27 C. Malitesta, F. Palmisano, L. Torsi and P. G. Zambonin, Anal. Chem., 1990, 62, 2735-2740.

28 T. W. Sohn, P. W. Stoecker, W. Carp and A. M. Yacynych, Electroanalysis, 1991, 3, 763-766.

29 J. D. Craig and R. D. O'Neill, Analyst, 2003, 128, 905-911.

30 S. Myler, S. Eaton and S. P. J. Higson, Anal. Chim. Acta, 1997, 357, 55-61.

31 J. K. Leypoldt and D. A. Gough, Anal. Chem., 1984, 56, 2896-2904.

32 J. J. Gooding and E. A. H. Hall, Electroanalysis, 1996, 8, 407-413.

33 J. P. Lowry and R. D. O'Neill, Electroanalysis, 1994, 6, 369-379.

34 C. P. McMahon, S. J. Killoran, S. M. Kirwan and R. D. O'Neill, Chem. Commun., 2004, 2128-2130.

35 C. P. McMahon, S. J. Killoran and R. D. O'Neill, J. Electroanal. Chem., 2005, 580, 193-202.

36 D. Compagnone, G. Federici and J. V. Bannister, Electroanalysis, 1996, 7, 1151-1155.

37 S. V. Sasso, R. J. Pierce, R. Walla and A. M. Yacynych, Anal. Chem., 1990, 62, 1111-1117.

38 Y. N. Zhang and G. S. Wilson, Anal. Chim. Acta, 1993, 281, 513-520.

39 G. Segovia, A. Porras and F. Mora, Neurochem. Res., 1997, 22, 1491-1497.

40 M. Miele, M. Berners, M. G. Boutelle, H. Kusakabe and M. Fillenz, Brain Res., 1996, 707, 131-133.

41 G. S. Wilson and Y. B. Hu, Chem. Rev., 2000, 100, 2693-2704.

42 A. Belay, A. Collins, T. Ruzgas, P. T. Kissinger, L. Gorton and E. Csoregi, J. Pharm. Biomed. Anal., 1999, 19, 93-105.

43 N. G. Patel, A. Erlenkotter, K. Cammann and G. C. Chemnitius, Sens. Actuators, B, 2000, 67, 134-141.

44 J. A. Cox, P. M. Hensley and C. L. Loch, Microchim. Acta, 2003, 142, $1-5$.

45 J. Jezkova, E. I. Iwuoha, M. R. Smyth and K. Vytras, Electroanalysis, 1997, 9, 978-984.

46 E. Mikeladze, A. Schulte, M. Mosbach, A. Blochl, E. Csoregi, R. Solomonia and W. Schumann, Electroanalysis, 2002, 14, 393-399.

47 W. H. Oldenziel and B. H. C. Westerink, Anal. Chem., 2005, 77, 5520-5528.

48 T. Hoshi, H. Saiki, S. Kuwazawa, C. Tsuchiya, Q. Chen and J. I. Anzai, Anal. Chem., 2001, 73, 5310-5315.

49 W. J. Li, Z. Wang, C. Q. Sun, M. Xian and M. Y. Zhao, Anal. Chim. Acta, 2000, 418, 225-232.

50 M. K. Ram, P. Bertoncello, H. Ding, S. Paddeu and C. Nicolini, Biosens. Bioelectron., 2001, 16, 849-856.

51 J. P. Santos, E. R. Welsh, B. P. Gaber and A. Singh, Langmuir, 2001, 17, 5361-5367.

52 R. D. O'Neill, J. P. Lowry and M. Mas, Crit. Rev. Neurobiol., 1998, 12, 69-127. 